\title{
Gross Domestic Regional Product, Population and Environmental Quality: Analysis of 33 Provinces in Indonesia
}

\author{
Ina Indriana ${ }^{1^{*}}$, Nor Asmat Ismail ${ }^{2}$, Siti Rahyla Rahmat ${ }^{3}$ \\ ${ }^{1}$ University of Sultan Ageng Tirtayasa, Indonesia \\ 2,3Universiti Sains Malaysia, Malaysia \\ Corresponding Author: inaindriana@untirta.ac.id ${ }^{\left.1^{*}\right)}$
}

Keywords : Gross Domestic Regional Product, Population, Environmental Quality

\begin{abstract}
:
In recent years environmental problems have become the focus of public attention in the world. This research was conducted to determine the impact of Gross Domestic Regional Product growth, population growth on environmental quality. This study involved 33 provinces in Indonesia as a unit of analysis. Secondary data was collected from the Indonesian Central Bureau of Statistics. Data analysis was performed using panel least square with software Warp-PLS version 6.0. Previous research deployed $\mathrm{CO} 2$ Emission and pollution as an indicator of environmental performance, this research used a score of environmental quality index which covers water quality index, index of air quality and index of forest cover. Findings showed Gross Domestic Product and population have a negative effect on environmental quality. This research indicates government need to that encourages the household and industrial sectors to use environmentally friendly energy, limits and controls the conversion of forests and agricultural land into land for settlement, agriculture, and industry, and encourages the household and industrial sectors to provide waterways and ensure that liquid waste discharged into rivers, lakes or waterways does not harm the environment.
\end{abstract}




\section{Introduction}

High birth rates each year trigger a large demand for goods and services (Giljum, Burger, Hinterberger, Lutter, \& Bruckner, 2011). Human activities in meeting their needs are very dependent on the resources provided by the environment. Increasing population growth demands the fulfillment of more needs so that the development process continues to meet the needs of human life. Previous research proves that economic growth and population growth contribute greatly to the decline in environmental quality as assessed by increasing pollution, carbon emissions and disposal wastes (Acaravci \& Ozturk, 2010; Al Mamun, Sohag, Hannan Mia, Salah Uddin, \& Ozturk, 2014; Casey \& Galor, 2017; Jalil \& Mahmud, 2009; Soytas \& Sari, 2009; S. S. Wang, Zhou, Zhou, \& Wang, 2011). Demand for products and services drives industrial growth. The relationship between economic growth and environmental quality is highly dependent on three important mechanisms such as the scale of production, the composition or means of production and the use of technology for production. The growing demand triggers more production. This larger scale of production requires a greater supply of resources (raw materials, energy, water) which force exploitation of the natural environment and decreases environmental quality.

The Hague Environment Council in 1996 defines environmental quality as the quality of the parts that make up an area such as nature, open space, infrastructure, the built environment, physical environmental facilities, and natural resources (Kamp, Leidelmeijer, Marsman, \& Hollander, 2003). Study of Bostenaru, Panagopoulos, \& Duque (2016) revealed that environmental quality is an important element in human well-being because the quality of life is fundamentally influenced by the quality of the physical environment. The quality of human health is influenced by the quality of the environment (Nowak, Hirabayashi, Bodine, \& Green, 2014). Mcmichael, Woodruff, \& Hales (2006) revealed drastic environmental changes can reduce the quality of human health through climate change. Water, air, land, forests and access to green space are basic human needs (Pretty, Peacock, Sellens, \& Griffin, 2005). Environmental quality is assessed based on the quality of water, air, and soil. Environmental degradation causes ecosystem imbalance.

This phenomenon occurs throughout the world including Indonesia. The average population growth in Indonesia per year is $1.3 \%$ (Statistical Central Agency). Along with this population growth, the consumption level also increased by an average of 2.6 percent per year from 2010-2017 (Indonesian Ministry of Agriculture, 2018). Industrial growth triggered by population growth reduce the environmental quality. The declining environmental quality cause various natural disasters such as floods, landslides, tidal waves, and forest fires. According to environmental statistics report, in 2016 there were 820 cases of flooding, in the following year the number increased to 980 cases. While landslides, in 2016 as many as 599 cases increased to 850 cases in 2017. In contrast to the tidal wave, the number of cases in 2017 was smaller than in 2016, each of 11 cases and 23 cases. In 2017, forest fires have dropped dramatically, only one case, in the previous year it was 178 cases. In addition to having an impact on the environment, environmental degradation also affects health. Hazardous and toxic materials waste, especially heavy metals, can damage the brain's 
nervous system, and cause congenital defects to death. (Statistical Central Agency, 2018). The handling of the problem is estimated to spend between 2.5 and 7.0 percent of Gross Domestic Products (GDP) before 2001. In 2005, the government spent US \$ 6 billion or more than $2 \%$ of the GDP, the budgets were allocated on health, water, tourism, and other welfare related to poor sanitation. In 2007, the government had to spend US $\$ 5.5$ billion to overcome health problems due to indoor and outdoor air pollution (World Bank, 2009).

According to environmental performance index (EPI) published by Yale University, Indonesia's environmental performance left far behind compared to other ASEAN member countries such as Singapore, Malaysia, Brunei Darussalam, and Thailand. In 2018, Indonesia's environmental performance ranks $133^{\text {th }}$ in the world. Meanwhile, Singapore, Brunei Darussalam, Malaysia, and Philippines rank higher than Indonesia. The Indonesia environmental performance ratings among ASEAN countries are presented on Table 1.

Table 1. Environmental Performance of ASEAN Countries

\begin{tabular}{lrrrr}
\hline Country & \multicolumn{4}{c}{ EPI Rank } \\
& 2010 & 2014 & 2016 & 2018 \\
\hline Indonesia & 134 & 112 & 107 & 133 \\
Malaysia & 54 & 51 & 63 & 75 \\
Philippines & 51 & 114 & 66 & 82 \\
Singapore & 28 & 4 & 14 & 49 \\
Thailand & 67 & 78 & 91 & 121 \\
Laos & 80 & 127 & 153 & 153 \\
Myanmar & 110 & - & 148 & 138 \\
Brunei Darussalam & 72 & 37 & 98 & 53 \\
Viet Nam & 85 & 136 & 131 & 132 \\
Cambodia & 148 & 145 & 146 & 150 \\
Timor-Leste & - & 132 & 138 & 125 \\
\hline
\end{tabular}

Source: Environmental Performance Index, Yale University

This research was conducted to investigate the impact of GDRP per capita and population on environmental quality. In this study, environmental quality was proxied by environmental quality index. This indicator is infrequently used in the previous study. The environmental index is a comprehensive indicator that be able to capture boarder aspects of the ecosystems (Almeida, Cruz, Barata, \& García-Sánchez, 2017). The environmental quality formed by many factors, such as air, water, and solid waste pollution, among other factors, as well as environmental pollution control and environmental pollution per unit area, therefore environmental quality and cannot simply replaced by single pollutant (Zhou \& Li, 2020).

The quality of the environment is influenced by several factors, namely human development, economic growth Babu and Datta (2013), per capita income, trade openness (Shahbaz, Sharma, Sinha, \& Jiao, 2021), FDI, industrialization (Munir \& Ameer, 2020), carbon emissions ( Wang \& Jiang, 2019), population growth, energy consumption (Khan, Hou, \& Phong, 2021), and urbanization (Bashir, Susetyo, Suhel, \& Azwardi, 2021). Many studies have been conducted to determine the relationship between economic growth, population growth and environmental quality, however, the results of the study have not provided consistent conclusions (Acaravci \& Ozturk, 2010). Low environmental quality is characterized by 
environmental degradation, including lack of clean water and sanitation, deforestation, municipal waste, and sulfur dioxides and carbon emissions (Panayotou, 2003). According to European Environmental Agency (2004) environmental quality is a general term that can refer to: various characteristics such as purity or pollution of air and water, noise, access to open spaces, and the visual effects of buildings, and the potential effects that these characteristics may have on physical and mental health.

According to Indonesian Ministry of Environment and Forestry, environmental quality proxied by environmental Quality Index (EQI) that constructed by air quality index, water quality index and land cover quality index. The water quality index is evaluated based on monitoring the result of river water quality. Monitoring is carried out based on parameters including Total Suspended Solid (TSS), Dissolved Oxygen (DO), Biochemical Oxygen Demand (BOD), Chemical Oxygen Demand (COD), Total Phosphate, Faecal Coli, and Total Coliform. Air quality monitoring indexes were carried out in transportation, residential, industrial, and commercial areas in $\mathbf{1 5 0}$ districts /cities, and which focused on the parameters of Sulphur Dioxide $\left(\mathrm{SO}_{2}\right)$ and Nitrogen Dioxide $\left(\mathrm{NO}_{2}\right)$. The land cover quality index was calculated by summing up the land cover index, forest performance index, land cover condition index, water body conservation index and the habitat condition index. The index value of land cover quality is influenced by several factors including land clearing activities, forest and /or land fires, illegal logging, forest and/or land rehabilitation activities, coastal area rehabilitation, post-mining land restoration activities, and restoration of hazardous and toxic waste of contaminated land (Indonesia-Ministry of Environmental and Forestry, 2018)

Population is identified as a main contributor of environment degradation. population size is closely associated with some source of emissions such as waste product. The increase in population causes to increase in consumption, which must fulfil through increase in production. Production activities generate waste product, which tiggers pollution and degradation of the natural resources (Mansoor \& Sultana, 2018). Highlighting the previous argument, the population growth triggers the economic growth. The growth of economic is marked by massive development process and industrial growth. The development conducted relies on natural resources (Giljum et al., 2011). The purpose of development is to improve the standard of living of humans, materially, that is measured by income. The higher the income earned, the more income that can be spent. Research shows that consumption affects economic growth and environmental quality (Ivanova et al., 2016; Yuan, Ren, \& Chen, 2015). Economic activity grew rapidly along with the increasing population. The study of Mazur (1994) concluded that the population growth induced by non-population growth residential and commercial, industrial, and transportation had positive impact on the increasing of energy consumption. Massive fossil energy usage result in $\mathrm{CO} 2$ emission that trigger greenhouse gas emission and climate change. (Santosa et al., 2008) revealed that after the 1998 economic crisis, air pollution in Indonesia was caused by the large consumption of fossil fuels by the industrial and transportation sectors. The study of Bashir et al. (2021) showed that in the short run urbanization and energy consumption triggered $\mathrm{CO} 2$ emissions. The similar conclusion revealed that economic growth increases the CO2 emission (Wang \& Jiang, 2019). 
Business expansion is done by building factories and expanding the marketing area. The increasing number of industrial creates more jobs, increases income and triggers more production and consumption. However, many factories were built in forest, agricultural and residential areas. Converting forest area into another area causes deforestation. The deforestation is identified as the major contributor of greenhouse gas emission. Rosero-bixby \& Palloni (1998) argued that the relationship between population growth and deforestation is analysed through two assumptions, the population growth led to forest land shortage and increasing demand of wood and firewood. The reduction of forest land due to the increasing demand for land for agricultural land, the demand for land for settlements continues to increase, the distribution of land is unequal, the preservation of agricultural technology that supports extensification over-intensification. Converting forest into another area result in the change of forest function that triggers landslides, floods, droughts and food shortages (Hidayati, Vidyattama, \& Gordon, 2016). The change of forest function also led to diminish of clean water supply and water pollution (Juma, Wang, \& Li, 2014). The population growth and economic growth also drive the growth of waste. A study showed that untreated waste that directly dropped into river or waterway cause water pollution (Rajput, Pandey, Bhadauria, \& India, 2017). In summary, it can be concluded that environmental quality is affected by economic growth and population (POP).

Table 2. Previous Study

\begin{tabular}{|c|c|c|}
\hline Author & Variables & Finding \\
\hline $\begin{array}{l}\text { Wang and Jiang } \\
\text { (2019) }\end{array}$ & $\begin{array}{l}\text { Independent variable: } \\
\text { Economy } \\
\text { Dependent variable: } \\
\text { CO2 emissions }\end{array}$ & $\begin{array}{l}\text { Rapid economic growth } \\
\text { significantly increased } \\
\text { emissions. } \\
\text { Economics growth marked by the } \\
\text { increasing on investment in fixed } \\
\text { assets. Fixed assets, labor input, } \\
\text { have positive impact on CO2, } \\
\text { emission. Lower coal consumption } \\
\text { reduces } \mathrm{CO} 2 \text { emission. }\end{array}$ \\
\hline $\begin{array}{l}\text { Khan, Hou, and } \\
\text { Phong (2021) }\end{array}$ & $\begin{array}{l}\text { Independent variable: } \\
\text { Natural resources } \\
\text { Population growth } \\
\text { Energy consumption } \\
\text { Dependent variable: } \\
\text { Environmental quality } \\
\text { proxied by } \\
\text { ecological footprint and } \\
\text { CO2 emissions }\end{array}$ & $\begin{array}{l}\text { Natural resources and renewable } \\
\text { energy consumption improve } \\
\text { environmental quality in the long } \\
\text { run, while population growth and } \\
\text { non-renewable } \\
\begin{array}{l}\text { consumption energy } \\
\text { environmental quality. }\end{array}\end{array}$ \\
\hline
\end{tabular}

Almeida et al. Independent variable: The EKC hypothesis is not proved. (2017) Economic Growth proxied The economic growth alone was by GDP per-capita. not enough to improve environmental quality. 


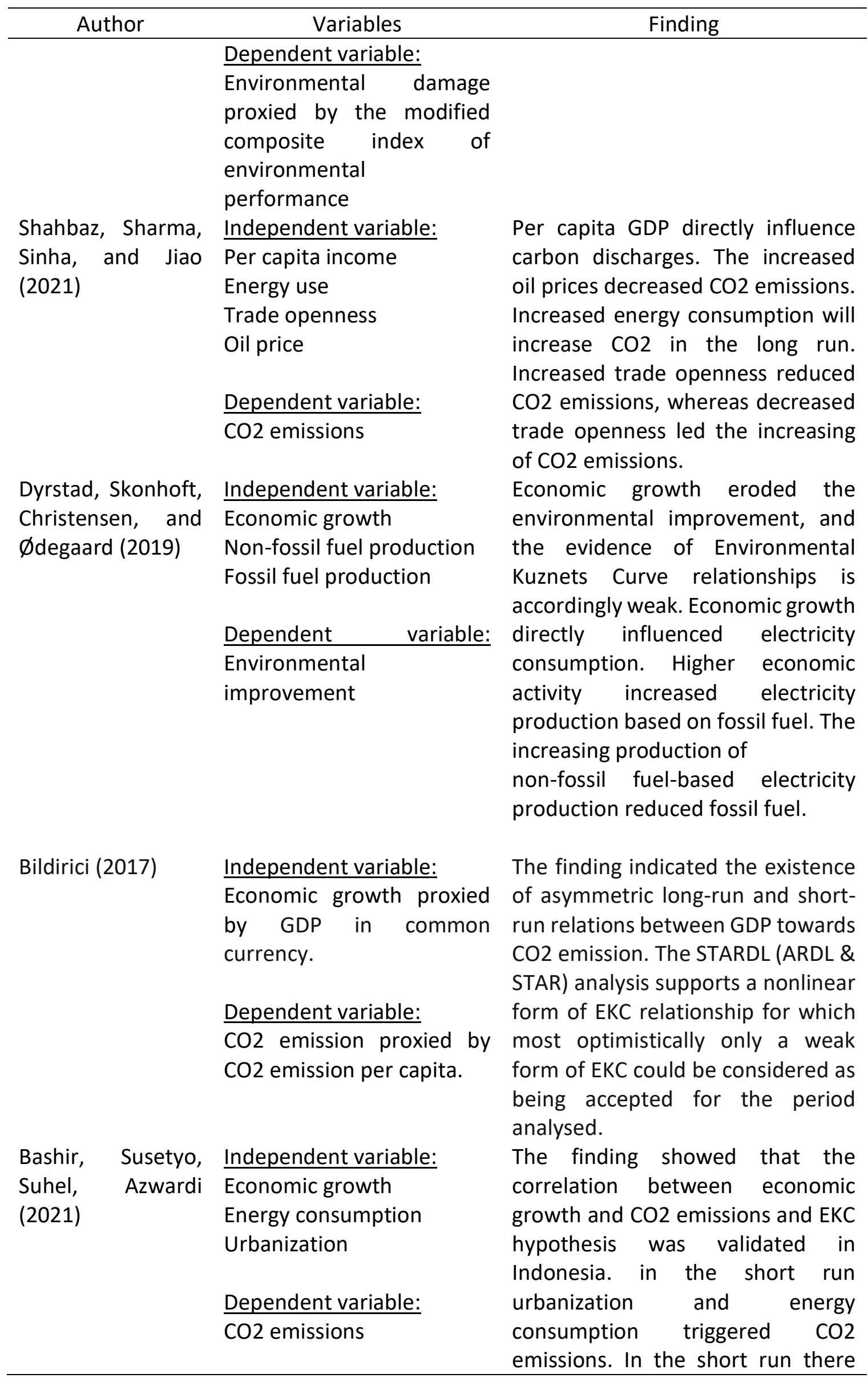




\begin{tabular}{|c|c|c|}
\hline Author & Variables & Finding \\
\hline & & $\begin{array}{llr}\text { was no } & \text { correlation between } \\
\text { economic growth and } \mathrm{CO} 2 \\
\text { emissions. }\end{array}$ \\
\hline \multirow[t]{2}{*}{$\begin{array}{l}\text { Munir and Ameer } \\
\text { (2020) }\end{array}$} & $\begin{array}{l}\text { Independent variable: } \\
\text { FDI } \\
\text { Economic growth } \\
\text { Industrialization }\end{array}$ & $\begin{array}{l}\text { The results of the NARDL model } \\
\text { indicated that a long-run } \\
\text { correlation exists between FDI, } \\
\text { economic growth, industrialization, } \\
\text { and } \mathrm{CO} 2 \text { emissions in }\end{array}$ \\
\hline & $\begin{array}{l}\text { Dependent variable } \\
\text { Environmental quality } \\
\text { proxied by } \mathrm{CO} 2 \text { emission }\end{array}$ & $\begin{array}{l}\text { Pakistan. An increase in FDI, } \\
\text { economic growth and } \\
\text { industrialization have a positive and } \\
\text { significant effect on } \mathrm{CO} 2 \text { emissions } \\
\text { in the long run. While a decrease in } \\
\text { FDI, economic growth and } \\
\text { industrialization have a negative } \\
\text { and insignificant effect on CO2 } \\
\text { emissions. }\end{array}$ \\
\hline $\begin{array}{l}\text { Evans, Opoku, and } \\
\text { Kofi (2020) }\end{array}$ & $\begin{array}{l}\text { Independent variable: } \\
\text { Economic growth } \\
\text { Population growth } \\
\text { Trade } \\
\text { FDI } \\
\text { Industrialization } \\
\text { Dependent variable: } \\
\text { Environmental impact } \\
\text { (CO2, N2O, GHGs, CH4) }\end{array}$ & $\begin{array}{l}\text { The effect of industrialization on } \\
\text { the environment is insignificant. } \\
\text { However, the foreign direct } \\
\text { investment significantly impacted } \\
\text { on the environment. The } \\
\text { environmental impact of trade } \\
\text { openness is mixed, and the impact } \\
\text { was sensitive to the environmental } \\
\text { proxy used. While the population } \\
\text { growth endangers the } \\
\text { environment. This confirms the } \\
\text { PHH for the case of FDI, an increase } \\
\text { in FDI is found to likely decrease } \\
\text { improvement in environmental } \\
\text { quality. This outcome is consistent } \\
\text { with the EKC or the inverted U- } \\
\text { shaped hypothesis which } \\
\text { postulates that as an economy } \\
\text { grows (GDP per capita increases), } \\
\text { the emissions of pollution (CO2) } \\
\text { increase, attains a peak, and then } \\
\text { begins to fall. }\end{array}$ \\
\hline $\begin{array}{l}\text { Alvarado and } \\
\text { Toledo (2016) }\end{array}$ & $\begin{array}{l}\text { Independent variable: } \\
\text { Economic growth } \\
\text { Real GDP } \\
\text { Urbanization }\end{array}$ & $\begin{array}{l}\text { The environmental degradation is } \\
\text { caused by a significant reduction in } \\
\text { vegetation cover due to expansion } \\
\text { of agricultural land, urbanization, } \\
\text { and dependence on income from } \\
\text { primary exports. The evidence did }\end{array}$ \\
\hline
\end{tabular}






\section{Research Method}

This study is designed to analyse the impact of the growth of Gross Domestic Regional Product (GDRP), population growth on environmental quality. The multiple regression applied in the to analyse the data. There are two dependent variables used, GDRP and population, independent variables used by environmental quality. The GDRP data was obtained from the website of the Indonesian Statistical Central Agency. Meanwhile, the population number is assessed by the number of permanent residents in one province, the quality of the environment is measured based on the Environmental Quality Index (EQI) issued by the Ministry of Environment and Forestry of the Republic of Indonesia. This study uses pool data from 33 provinces in Indonesia for the period 2015, 2016, and 2017. Partial Least Square analysis is applied to test the effect of dependent and independent variables. Data analysis 
was performed using software Warp-PLS 6 version. This software can be applied to analysis time series, cross sectional, and panel data. Variables of the study includes observed variable with formative indicator. PLS-SEM allows to analysis variable observed with formative indicators. The study uses small data, Warp-PLS is applicable for study with small sample. PLSSEM is a very powerful analytical method because it can overcome problems that occur in Ordinary Least Square (OLS) such as data that must be normally distributed and free from multicollinearity. In addition, PLS also does not require certain scale measurements and large sample sizes (Ghozali, 2008).

The steps taken to use PLS:

1. Determine the model specifications, this stage is related to the formulation of the inner and outer models. The inner model or structural model describes the relationship between the constructs (variables) that are evaluated. The relationship between the constructs can be seen from the significance of the P-value. The outer model is used to assess the relationship between indicators and constructs. The outer model is used to determine the extent to which the indicators used are valid and reliable to represent a construct or variable. Validity testing is done through testing construct validity, predictive validity, and content validity. Reliability testing is done through internal consistency reliability testing. To measure the internal consistency of the PLS application, the composite reliability value was used. For reflexive indicators, the reliability measurement can be seen from the reliability indicator which explains the magnitude of the variance of the indicator in explaining the latent construct and composite reliability, measuring the reliability of the construct as a whole, if the loading factor value of each indicator $>0.7$, the indicators are declared to meet reliability indicator criteria. The value of composite reliability can be seen from the reliability construct, if the value is $>0.7$, the indicators used meet the reliability criteria or by looking at the value of variance extracted (AVE) which is greater than $50 \%$ or greater than the variance of the indicators described. Especially for variables with formative indicators, reliability testing is carried out by looking at the weight significance value of the resampling procedure. The significance value $(P<0.05)$ indicates that the indicator meets the criteria for the reliability indicator. Testing with formative indicators is possible between independent constructs/variables having a mutually influencing relationship (collinearity problem) which is indicated by the R2 value $>0.80$, the Variance Inflation Factor (VIF) value $>5$ or the tolerance value $<0.20$, if this happens then the ability of the variable independent in explaining to be biased.

2. Evaluate the inner model. The assessment of the quality of the model is based on the ability of exogenous (independent) variables to predict changes in endogenous (dependent) variables. Assessment is done by looking at the Coefficient of determination (Adjusted R2). Adjusted R2 0.70 shows the ability of the model to explain changes in the dependent variable (variance) is strong. Adjusted R2 0.45 and 0.25 indicate the model's ability to explain moderate and weak variance. Model evaluation can also be done by testing the partial F-test (effect size). The Warp-PLS 5.0 
and 6.0 applications can calculate the effect size $(f 2)$ value automatically, the $f 2$ value of 0.35 indicates that the influence of the predictor variable (independent) is large, the $f$ values of 0.15 and 0.02 indicate that the influence of the predictor variable is moderate and weak. The value of predictive relevance (Q2) is used to assess the model, the value of Q2 > 0 indicates the model has predictive relevance, $\mathrm{Q} 2<0$ the model does not have predictive relevance.

\section{Result and Discussion}

The Warp-PLS output shown in table3, the effect of GDRP and population on environmental quality is significantly negative.

Table 3. Path Coefficient, P-Value, Adjusted R2, Q2 Coefficient

\begin{tabular}{|c|c|c|c|c|c|c|}
\hline $\begin{array}{l}\text { Model fit } \\
\text { indices }\end{array}$ & Result & $\begin{array}{c}\text { Path } \\
\text { Coefficient }\end{array}$ & P-Value & Adjusted $\mathrm{R}^{2}$ & $\begin{array}{c}\mathrm{Q}^{2} \\
\text { coefficient }\end{array}$ & $F^{2}$ \\
\hline $\begin{array}{l}A P C=0.309 \\
p<0.001\end{array}$ & Accepted & $\begin{array}{l}\text { GDRP--EQ = } \\
-0.192 \\
\text { Pop-EQ = } \\
-0.427\end{array}$ & $\begin{array}{l}<0.023 \\
<0.001\end{array}$ & 0.197 & 0.213 & $\begin{array}{l}\text { GDRP = } \\
0.034 \\
\text { Pop }= \\
0.179\end{array}$ \\
\hline $\begin{array}{l}\text { ARS }=0.213 \\
p<0.001\end{array}$ & Accepted & & & & & \\
\hline $\begin{array}{l}\text { AARS }= \\
0.197 \\
p<0.001\end{array}$ & Accepted & & & & & \\
\hline $\begin{array}{l}\text { AVIF }=1.184, \\
\text { p ideally <= } \\
3.3\end{array}$ & Accepted & & & & & \\
\hline $\begin{array}{l}\text { AFVIF }=1.271 \\
\text { ideally }<=3.3\end{array}$ & Accepted & & & & & \\
\hline $\begin{array}{l}\text { GOF }=0.462, \\
\text { large }>=0.36\end{array}$ & Accepted & & & & & \\
\hline $\begin{array}{l}S P R=1 \\
\text { ideally } 1\end{array}$ & Accepted & & & & & \\
\hline $\begin{array}{l}\mathrm{RSCR}=1 \\
\text { ideally } 1\end{array}$ & Accepted & & & & & \\
\hline $\begin{array}{l}\text { SSR }=1 \\
\text { acceptable if } \\
>=0.7\end{array}$ & Accepted & & & & & \\
\hline $\begin{array}{l}\text { NLBCDR }=1 \\
\text { acceptable if } \\
>=0.7\end{array}$ & Accepted & & & & & \\
\hline
\end{tabular}

The Table 3 indicates that the environmental quality is negatively and significantly influenced by GDRP and population growth. It can be seen from regression coefficient value (-) 0.192 and (-) 0.427 . Whereas the significancy of both variables in influencing environmental quality showed on $P$ Values 0.023 and $<0.001$. The finding implies that one rupiah increase in GDRP per capita reduces environmental quality by 0.192 , and an increase in one person reduces the quality of the environment by 0.427 . The adjusted R-squared 0.197 
implies that the ability of environmental variables to explain variations in changes from the GDRP variable and population is 0.197 or 19.7 percent. This finding indicates that environmental quality is influenced by other variables outside model as much as 80.3 percent. The influence of the population on environmental quality is greater than the effect of the Gross Domestic Regional Product on environmental quality. This can be seen from the regression coefficient of $-0.427>-0.192$, the contribution of each independent variable to the quality of the environment in sequential order. Although the evidence shows that the two variables have a significant influence on environmental quality, the effect is relatively small, only 19.7 percent. The full value of Collin VIF 1,271 > 1 shows that the model is free from the problem of collinearity. The Q-squared value $0.213>0$ indicates that the model has predictive relevance. The standard error is 0.095 for GDRP and population 0.089 shows that the model is significant and there is no collinearity problem. Effect size $0.034<$ from 0.15 for GDRP and $0.179<0.25$ for the population shows that the predictor of variables for GDRP is in the small category and moderate for the population variable. The Table 3 also shows that the model is a good model because all the criteria of the fit model test are accepted. Fit models are represented by APC $=0.309$, with $\mathrm{p}<0.001, \mathrm{ARS}=0.213, \mathrm{P}<0.007, \mathrm{AARS}=0.197, \mathrm{AVIF}=$ 1,184 , acceptable if $<=5$, ideal $<=3.3$, GOF $=0.462$, small $>=0.1$, medium $>=0.25$, large $>=$ $0.35, \mathrm{SPR}=1$, acceptable if $>=0.9$, ideal $=1, \mathrm{SSR}=1$ acceptable if $>=0.7, \mathrm{NLBCDR}=1,000$ acceptable if $>=0.7$.

This study concludes that the Gross Domestic Regional Product and population have a negative effect on environmental quality in 33 provinces in Indonesia. This study support Robbi, Ismail, Hoetoro, \& Muhammad (2019) their study showed that per capita income, trade openness, energy consumption, and population impact on environmental degradation $\left(\mathrm{CO}_{2}\right.$ emission) in Indonesia. The economic growth (GDRP) and population growth trigger the increasing of energy consumption. Population growth relies on the composition of production and consumption. The population growth stimulates an increase in emissions which led to air quality to decline (Cramer 1998). The report of Statistical Central Agency showed that the energy consumption by household increase significantly from 2010 to 2015 , the increasing is almost $10 \%, 20.99 \%$ (2010) to $30 \%$ (2015), in 2016, the percentage slight decrease it was 29.4\%. However, in 2017 the percentage reaches $30.7 \%$. Population growth affects industrial growth, and the economic growth is stimulated by industrial activity. The report of Statistical central Agency shows that manufacturing company number significantly increase from 2010 to 2015 , the number was 23,340 unit (2010), in 2015 it was 26.322 unit. The number rise significantly in 2016 (35,163 unit) and slight decrease in 2017 (33,577 unit). The manufacturing sector is identified as intensive user of fossil fuels. The need of fossil fuels increases along with the increasing of manufacturing companies. The percentage of energy used by construction sector and manufacturing sector tend to decrease from 2010 to 2015 . The percentage was 40.1\% (2010) and 36.51\% (2015). In 2016 and 2017, it was 36.23\% and 31.60 respectively. In contrast, greenhouse gas emission produced tend to incline, 453,235 Gg CO²e (2010), 536,306 Gg CO2e (2015), 538,025 Gg CO2e (2016), and 562,244 Gg CO2e. 
The population growth and GDRP growth led to reducing forest and agriculture area. The Infrastructure development, agricultural land clearing, residential construction and mining land that continues to grow along with population growth causes deforestation (Hidayati et al., 2016). The Ministry of Agriculture's report shows that the decline in agricultural land is due to the conversion of agricultural land into areas for industry, housing, facilities, and infrastructure. The largest decrease occurred from 2012 to 2013 with 212,576 hectares and 25,638 hectares between 2016 and 2017. Permatasari et al. (2016) showed that agricultural land shrinks by about $6 \%$ because the land is converted to use for industrial land, housing, roads, and others in Jombang, East Java. Another evidence revealed by Robbany et al. (2019), showed that the vegetation in the Metropolitan (Jakarta, Bogor, Tangerang, and Bekasi) area reduced significantly from 2001 to 2015; the reduction was around 8\%, from 54\% (2001) to 46\% (2015); in the following years, it is expected to fall to $30 \%$.

The economic growth and population growth trigger decreasing of water quality. Deforestation and conversion of agricultural land into residential and industrial lands cause reduced water quality. The absence of absorption land causes river water to be exposed to pollution runoff from agricultural land (Juma et al., 2014). Household and industrial waste that is dumped directly into rivers is another cause of declining water quality (Rajput et al., 2017). The evidence from Kido et al. (2009) showed lack of drainage system in developing countries includes Indonesia causes industrial, agricultural and domestics water is directly discarded into rivers. The report of Indonesia Ministry of Environment and Forestry (2013) indicates that sources of water pollution come from unmanaged domestic and industrial wastewater, domestic waste, excessive water use, and poor land use arrangement.

\section{Conclusion}

Economic growth and population growth trigger production and consumption activities. Production and consumption activities require the availability of adequate resources. Resources such as energy are provided by the natural environment. The increase in demand due to the increase in population increases energy use, the increasing use of energy causes emissions which have an impact on decreasing air quality. Economic and population growth causes demand for land for settlement, agriculture, industry, and other infrastructure to increase. This conversion of forest and agricultural land causes deforestation which triggers a decline in land quality, air, and water quality. To mitigate environmental degradation from economic growth and population growth, the government need to encourage the household and industrial sectors to use environmentally friendly energy, limits and controls the conversion of forests and agricultural land into land for settlement, agriculture, and industry, and encourages the household and industrial sectors to develop waterways and ensure that liquid waste discharged into rivers, lakes or waterways does not harm the environment.

\section{References}

Acaravci, A., \& Ozturk, I. (2010). On the relationship between energy consumption, CO2emissions and economic growth in Europe. Energy, 35(12), 5412-5420. https://doi.org/10.1016/j.energy.2010.07.009

Al Mamun, M., Sohag, K., Hannan Mia, M. A., Salah Uddin, G., \& Ozturk, I. (2014). Regional 
differences in the dynamic linkage between CO2emissions, sectoral output and economic growth. Renewable and Sustainable Energy Reviews, 38, 1-11. https://doi.org/10.1016/j.rser.2014.05.091

Almeida, T. A. das N., Cruz, L., Barata, E., \& García-Sánchez, I. M. (2017). Economic growth and environmental impacts: An analysis based on a composite index of environmental damage. Ecological Indicators, 76(x), 119-130. https://doi.org/10.1016/j.ecolind.2016.12.028

Alvarado, R., \& Toledo, E. (2016). Environmental degradation and economic growth : evidence for a developing country Environmental degradation and economic growth: Environment, Development and Sustainability, (August). https://doi.org/10.1007/s10668-016-9790-y

Bashir, A., Susetyo, D., Suhel, S., \& Azwardi, A. (2021). Relationships between Urbanization, Economic Growth , Energy Consumption , and CO 2 Emissions : Empirical Evidence from Indonesia. Journal of Asian Finance, Economics and Business, 8(3), 79-90. https://doi.org/10.13106/jafeb.2021.vol8.no3.0079

Bildirici, M. (2017). Economic growth and CO 2 emissions: an investigation with smooth transition autoregressive distributed lag models for the $1800-2014$ period in the USA. Environmental Science and Pollution Research. https://doi.org/10.1007/s11356-0170244-3

Bostenaru, M., Panagopoulos, T., \& Duque, J. A. (2016). Urban Planning with Respect to Environmental Quality and Human. Environmental Pollution, 208, 137-144. https://doi.org/10.1016/j.envpol.2015.07.038

Casey, G., \& Galor, O. (2017). Is faster economic growth compatible with reductions in carbon emissions? the role of diminished population growth. Environmental Research Letters, 12(1). https://doi.org/10.1088/1748-9326/12/1/014003

Dyrstad, J. M., Skonhoft, A., Christensen, M. Q., \& Ødegaard, E. T. (2019). Does economic growth eat up environmental improvements ? Electricity production and fossil fuel emission in OECD countries 1980 - 2014. Energy Policy, 125(October 2018), 103-109. https://doi.org/10.1016/j.enpol.2018.10.051

Evans, E., Opoku, O., \& Kofi, M. (2020). The environmental impact of industrialization and foreign direct investment. Energy Policy, 137(June 2019), 111178. https://doi.org/10.1016/j.enpol.2019.111178

Ghozali, I. (2008). Structural Equation Modeling Metode Alternatif with Partial Least Square (2nd ed.). Badan Penerbit Universitas Diponegoro.

Giljum, S., Burger, E., Hinterberger, F., Lutter, S., \& Bruckner, M. (2011). A comprehensive set of resource use indicators from the micro to the macro level. Resources, Conservation and Recycling, 55(3), 300-308. https://doi.org/10.1016/j.resconrec.2010.09.009

Hidayati, F., Vidyattama, Y., \& Gordon, C. (2016). Local Government Forestry Expenditure and Forest Land Cover: A Preliminary Lesson from Decentralized Indonesia 2 . Forest Contribution to Social and Economic Development in Indonesia. Economics and Finance in Indonesia, 62(3), 127-140. 
Indonesia-Ministry of Environmental and Forestry. (2018). Environmental Quality Index. Jakarta, Indonesia. Retrieved from www.menlh.go.id

Ivanova, D., Stadler, K., Steen-Olsen, K., Wood, R., Vita, G., Tukker, A., \& Hertwich, E. G. (2016). Environmental Impact Assessment of Household Consumption. Journal of Industrial Ecology, 20(3), 526-536. https://doi.org/10.1111/jiec.12371

Jalil, A., \& Mahmud, S. F. (2009). Environment Kuznets curve for CO2emissions: A cointegration analysis for China. Energy Policy, 37(12), 5167-5172. https://doi.org/10.1016/j.enpol.2009.07.044

Juma, D. W., Wang, H., \& Li, F. (2014). Impacts of population growth and economic development on water quality of a lake : case study of Lake. Environment Science Pollution Research. https://doi.org/10.1007/s11356-014-2524-5

Kamp, I. Van, Leidelmeijer, K., Marsman, G., \& Hollander, A. de. (2003). Urban environmental quality and human well-being Towards a conceptual framework and demarcation of concepts ; a literature study. Landscape and Urban Planning, 65, 5-18.

Khan, I., Hou, F., \& Phong, H. (2021). Science of the Total Environment The impact of natural resources, energy consumption, and population growth on environmental quality: Fresh evidence from the United States of America. Science of the Total Environment, 754, 142222. https://doi.org/10.1016/j.scitotenv.2020.142222

Kido, M., Suhaemi, Y. M., Sulastri, S., Hosokawa, T., Tanaka, S., Saito, T., ... Kurasaki, M. (2009). Comparison of General Water Quality of Rivers in Indonesia and Japan. Environment, Monitoring and Assessment, (156), 317-329. https://doi.org/10.1007/s10661-008-0487z

Mansoor, A., \& Sultana, B. (2018). Impact of Population, GDP and Energy Consumption on Carbon Emissions : Evidence from Pakistan Using an Analytic Tool IPAT. Asian Journal of Economics and Empirical Research, 183-190. https://doi.org/10.20448/journal.501.2018.52.183.190

Mazur, A. (1994). How Does Population Growth Contribute to Rising Energy Consumption in America ?, 15(5), 371-378.

Mcmichael, A. J., Woodruff, R. E., \& Hales, S. (2006). Climate Change and Human Health : Present and Future Risks. https://doi.org/10.1016/S0140-6736(06)68079-3

Munir, K., \& Ameer, A. (2020). Nonlinear effect of FDI, economic growth, and industrialization on environmental quality, 31(1), 223-234. https://doi.org/10.1108/MEQ-10-2018-0186

Nowak, D. J., Hirabayashi, S., Bodine, A., \& Green, E. (2014). Tree and forest effects on air quality and human health in the United States. Environmental Pollution, 193, 119-129. https://doi.org/10.1016/j.envpol.2014.05.028

Panayotou, T. (2003). Economic growth and the environment.

Permatasari, P. A., Fatikhunnada, A., Liyantono, Setiawan, Y., Syartinilia, \& Nurdiana, A. (2016). Analysis of Agricultural Land Use Changes in Jombang Regency, East Java , Indonesia Using BFAST Method. Procedia Environmental Sciences, 33, 27-35. 
https://doi.org/10.1016/j.proenv.2016.03.053

Pretty, J., Peacock, J. O., Sellens, M., \& Griffin, M. (2005). The mental and physical health outcomes of green exercise. International Journal of Environmental Health Research, (May 2014). https://doi.org/10.1080/09603120500155963

Rajput, R. S., Pandey, S., Bhadauria, S., \& India. (2017). Status of Water Pollution in Relation to Industrialization in Rajasthan. Rev Environ Healt.AOP, 1-8. https://doi.org/10.1515/reveh-2016-0069

Robbany, I. F., Gharghi, A., \& Traub, K. (2019). Land Use Change Detection and Urban Sprawl Monitoring in Metropolitan Area of Jakarta ( Jabodetabek ) from 2001 to 2015. Knowledge E, 2019, 257-268. https://doi.org/10.18502/keg.v4i3.5862

Robbi, I., Ismail, M., Hoetoro, A., \& Muhammad, A. (2019). Environmental Degradation in Indonesia 1969-2016. Advances in Economics, Business and Management Research, 144(Afbe 2019), 352-356.

Rosero-bixby, L., \& Palloni, A. (1998). Population and Deforestation in Costa Rica, 20(2).

Santosa, S. J., Okuda, T., Tanaka, S., Sciences, N., Sciences, N., \& Utara, S. (2008). Review Air Pollution and Urban Air Quality Management in Indonesia. Clean, 36, 466-475. https://doi.org/10.1002/clen.200800038

Shahbaz, M., Sharma, R., Sinha, A., \& Jiao, Z. (2021). Analyzing nonlinear impact of economic growth drivers on $\mathrm{CO} 2$ emissions : Designing an SDG framework for India. Energy Policy, 148(PB), 111965. https://doi.org/10.1016/j.enpol.2020.111965

Soytas, U., \& Sari, R. (2009). Energy consumption, economic growth, and carbon emissions: Challenges faced by an EU candidate member. Ecological Economics, 68(6), 1667-1675. https://doi.org/10.1016/j.ecolecon.2007.06.014

Wang, Q., \& Jiang, R. (2019). Is China's economic growth decoupled from carbon emissions ? Journal of Cleaner Production, 225, 1194-1208. https://doi.org/10.1016/j.jclepro.2019.03.301

Wang, S. S., Zhou, D. Q., Zhou, P., \& Wang, Q. W. (2011). CO2 emissions, energy consumption and economic growth in China: A panel data analysis. Energy Policy, 39(9), 4870-4875. https://doi.org/10.1016/j.enpol.2011.06.032

World Bank. (2009). Indonesian Environmental Analysis Report. Jakarta, Indonesia. Retrieved from www.worldbank.org/id

Yuan, B., Ren, H., \& Chen, X. (2015). The effects of urbanization, consumption ratio and consumption structure on residential indirect CO2emissions in China: A regional comparative analysis. Applied Energy, 140, 94-106. https://doi.org/10.1016/j.apenergy.2014.11.047

Zhou, A., \& Li, J. (2020). Impact of income inequality and environmental regulation on environmental quality: Evidence from China. Journal of Cleaner Production, 274, 123008. https://doi.org/10.1016/j.jclepro.2020.123008 